\title{
Community-Based Parenting Education Program in Improving Parents' Skills
}

\author{
Viena Rusmiati Hasanah \\ Nonformal Education Department, Faculty of Education Science, Universitas Pendidikan Indonesia, Indonesia \\ Corresponding e-mail: viena@upi.edu
}

\begin{abstract}
The study reports on community-based parenting education program in improving parents skills. It is carried out based on current empirical conditions in various circumstances of social issues that occur in the community, among others are divorce, dropout, street fighting between gangs of school students, promiscuity among school children, sexual violence, bullying, and so forth. These are social phenomena to look into closely. Globalization makes the role of parents in the family is increasingly important, indicating the importance of family education as pillar of education, particularly pertaining to similar cases as aforementioned, is first and foremost.Various parenting programs have been rolled out by various agencies to provide support for children care in the family. This study was intended to explore the implementation of community-based parenting program in improving the skills of parents. The research objectives were to determine the design of community-based parenting program, to examine the implementation and results of the implementation of the program. The study resulted in the following findings. Community-based parenting program conducted by Early Childhood Education Center in Geger Sunten Maribaya Lembang gave significant influence on the implementation of parenting education, particularly in terms of children care.
\end{abstract}

Keywords: Parenting education program, community, parent's skills

\section{INTRODUCTION}

Social issues recently occur in the community, among others are divorce, dropout, street fighting between gangs of school students, promiscuity among school children, sexual violence, bullying, and so forth. These are social phenomena to look into closely. Globalization makes the role of parents in the family is increasingly important, indicating the importance of family education as pillar of education, particularly pertaining to similar cases as aforementioned, is first and foremost.

Figure of National Education, Ki Hajar Dewantoro explains a system known as "Tri Centra" revealing that, "In children lives, there are three important places of interaction playing the role as the center for education involving family, school, and society". It shows that it is necessary for education to take place in school, environment, and especially family. Family is a part of education subsystem. Viewed from Law of National Education System which divides three types of education system (formal, nonformal, and informal), family is a part of informal education system.

Family is the smallest social unit in society. It is in line with Law Number 52 Year 2009 Regarding The Development of Population and Family Building, in Chapter II, Section Three, Article 4 Verse (2), stating that family building is intended to increase family quality to create comforts, peace, and hopes for better future so that prosperity and happiness can be attained. It means in general the aim of family building is for prosperity and survival (Puspitawati, 2012), and it includes 1) generate wellbeing of children by forgiveness, necessary for the family building and children growth; think positively, focusing on good nature; and run family system based on patrilineal system; 2) improve positive attitude, believing that children are gifts from God and thus parenting function is very 
influential to children; 3 ) adjust attitude between husbands and wives in terms of personalities, resolution strategiew, ways of gratitudes, spirituals; 4) improve family affection involving love, liking one another, and happy when to get together; 5) ways of improving family affection is by getting used to eat together, improving the quality and quantity of communication (questioning, listening, paying attention, and thinking positively) having vacation together, planning special moments together, maintaining uniquness of the family and maintaining tradition; 6) develop family spiritual by improving spiritual activities to develop the soul, to foster praying and to increase gratitudes to God; 7) improve daily family lives by applying proper disciplines, by educating children to behave nicely, and by improving the well-being of lifelong quality. This study is concerned with the exploration of the implementation of parenting program carried out within society, especially in Early Childhood Education Center of Geger Sunten Lembang. The aim is to find out design, implementation, results, supporting factors and obstacles in the implementation of community-based parenting program.

\section{LITERATURE REVIEW}

Family is the first social environment known by children. Interaction among family members generates self awareness, understanding that he functions as an individual and as a part of social creature.

Family constitutes a part of a subsystem of nonformal education. It is also a part of "Tri Centra" of education. Figure of National Education, Ki Hajar Dewantoro explains a system known as "Tri Centra" revealing that, "In children lives, there are three important places of interaction playing the role as the center for education involving family, school, and society".

Oates (2010:xii), states that parenting is an important element in children lives, parents in these case, are those who can provide them strength, prosperity, pride, social competency and citizenship values.

Parenting is a crucial element in the well-being of children. 'good' parenting is parenting that confers on children the benefits of resilience, well-being, self-worth, social competence and citizenship values. 'Good' parenting can take many forms; it is adaptable to local conditions and is a core component of culture.With adequate support from their prior experience and their living context, parents the world over can seek to assure their children's health, survival and full participation in cultural and economic activities. Ensuring survival and health, developing economic autonomy, and maximising cultural values are universal goals of parenting (Oates, 2010, p xii).

In Montgomery (2011), Le Vine (1977:20)

declares that the aims of parenting based on research on culture are as follows:

1) The physical survival and health of the child, including (implicitly) the normal development of his or her reproductive capacity during puberty,

2) the development of the child's behavioral capacity for economic selft-maintenance in maturity,

3) the development of the child's behavioral capacities for maximizing other cultural values. morality, prestige, wealth, religious piety, intellectual achievement, personal satisfaction, selft-realization as formulated and symbolically elaborated in culturally distinctive beliefs, norms, and ideologies.

Forms of parenting program are tactical and conceptual in nature. As explained by Sudjana (2001:31) stating that conceptual or academic parenting program emphasizes on the cognitive and theoretical aspects in its curriculum. It implies that affective and psychomotor aspects are not the focus of attention. Meanwhile, practical parenting program, putting emphasis on application, demonstrates that curriculum or the content of the program prioritizes the mastery of skills that are useful for the learners and their environment. Furthermore, practically, there are also other forms of parenting program in education institutions as Model of Parenting Education Program Implementation in Early Childhood Education Center (Kemendikbud, 2012:13) stated, and those include: Parents Class or Parents Meeting Class, Parents Involvement in Children Class/ Group; Parents Involvement in Gathering Event; Parents Consultation Day; home visit.

\section{METHODOLOGY}

\subsection{Research Setting}

The research method used is a qualitative approach with descriptive methods. The study site is conducted in Early Childhood Education Center of Gegersunten is situated in East Maribaya Street Km 13 Cibodas Rt/Rw 03/05 Area of Sunten Jaya Subdistrict of Lembang Regency of West Bandung. 


\subsection{Research Participant}

The targets of this parenting program were 10 parents who learn in Early Childhood Education Center of Gegersunten. The list of the participants are provided in the following table.

Table 3.1 List of Participants

\begin{tabular}{|l|l|l|l|}
\hline Num & Name & Occupation & Address \\
\hline 1 & Juhana & Farmer & Baru Tisuk \\
\hline 2 & Cucu & Farmer & Kp. Patrol \\
\hline 3 & Ina W & Farmer & Kp. Patrol \\
\hline 4 & Ening & Farmer & Sukamanah \\
\hline 5 & Yayah D & Farmer & Kp. Binong \\
\hline 6 & Rina & Farmer & Kp. Cibodas \\
\hline 7 & Ikah & Farmer & Batu loceng \\
\hline 8 & Nenden & Farmer & Kp. Patrol \\
\hline 9 & Cicini & Farmer & Kp P. Angling \\
\hline 10 & Ida H & Farmer & Kp P. Angling \\
\hline
\end{tabular}

Apart from the participants, respondent of research also involved one manager, two tutors, and two members of parenting program.

\subsection{Data Collection Techniques}

Data were obtained through interview and observation done during the process of program implementation. Research Instruments were developed to dig out data on design, implementation and result of parenting program implementation.

\section{RESULTS}

\subsection{Design of Parenting Program}

Parenting program and its management were organized based on participation, ensuring that everybody involved in the committee had clear tasks and functions. The targets of parenting program were 10 parents who learn in Early Childhood Education Center of Gegersunten. To determine goals of the parenting program, needs analyses were conducted. The results of needs analyses showed that to create parents having an ability to provide good parenting to children by paying attention to children psychology development at the earliest stage possible. Learning methods involved were audio visuals, sharing, and demonstration.

The parenting program was conducted for three months, from September to November within 48 hours. Each meeting took 1-2 hours depending on learning contracts with the participants of the program.

\subsection{The Implementation of Parenting Program}

Resource persons were taken from some experts depending on materials given. Those resource persons were tutors of Early Childhood Education Center of Gegersunten, doctors, nurses and so on. Materials given in the program are listed in Table 3.2 as follows.

Table 3.2 Material

\begin{tabular}{|l|l|}
\hline Num & Materials \\
\hline 1 & Introduction to Parenting \\
\hline 2 & Time to say "No" to Children \\
\hline 3 & $\begin{array}{l}\text { How to help children who have inferiority } \\
\text { complex }\end{array}$ \\
\hline 4 & Children Growth and Development \\
\hline 5 & Healthy Diet Pattern \\
\hline 6 & How to help children who speak harsh \\
\hline 7 & Understanding anger on children \\
\hline 8 & Can Children eat ice cream? \\
\hline
\end{tabular}

Learning methods were mostly attractive and gave learners (parents) more interests on the learning shown by degree of attendance and active learning involvement in the teaching learning process. It might be attributed to the varieties of learning methods such as demonstration, question and answer, and audio visual. Learning evaluation done by resource persons were carried out by observation technique, observing parents behavior development in the implementation of parenting to children.

\subsection{Results of Parenting Program}

Learning evaluation was done by resource persons in the implementation of parenting program in the classroom using question answer instruments and observation on direct practice of parenting to children. In general, the result of parenting program implementation showed that there was significant change of parents behavior in the provision of better parenting to their children, that they can .

\section{CONCLUSIONS}

Community-based parenting program conducted by Early Childhood Education Center of Gegersunten Maribaya Lembang gave a significant influence on 
parents knowledge development on parenting. Most parents who participated in parenting program in Early Childhood Education Center of Gegersunten could apply materials given in the program, viewed from the change of behavior in children parenting on daily basis. Knowledge of parents have seemed increasingly to get better by the existence of this parenting program. Therefore, it is recommended that manager can follow up the parenting program. It is also recommended that further researcher can investigate the effectiveness of the program in widely and thoroughly.

\section{REFERENCES}

John Oates, (2010). Supporting Parenting; Child and Youth Studies Group, The Open University Milton Keynes, United Kingdom

Kementrian Pendidikan dan Kebudayaan. (2012). Model Pelaksanaan Program Pendidikan Keorangtuaan di Lembaga Pendidikan Anak Usia Dini. Jakarta: Kemendikbud.

LeVine, R.A. (1977) 'Child rearing as cultural adaptation' in Leiderman, P.H., Tulkin, S.R. and Rosenfeld, A. (eds) Culture and Infancy: Variables in the human experience, New York, NY, Academic Press.

Montgomery, Heather (2009), An Introduction to Childhood: Anthropological Perspectives on Children's Lives, A John Wiley \& sons, Inc Publication

Puspitawati (2012). Gender dan Keluarga: Konsep dan Realita di Indonesia. PT IPB Press. Bogor.

Sudjana, D. (2001). Pendidikan Luar Sekolah: Wawasan Sejarah, Perkembangan, Falsafah dan Teori Pendukung Asas. Bandung: Falah Production.

Undang-Undang Republik Indonesia No 20 tahun 2003 tentang Sistem Pendidikan Nasional

Undang-Undang Republik Indonesia No. 52 Tahun 2009 tentang Perkembangan Penduduk dan Pembangunan Keluarga 